\title{
Residual Herbicide Dissipation in Vegetable Production
}

\author{
Timothy Grey and William Vencill \\ University of Georgia \\ United States
}

\section{Introduction}

The use of low density polyethylene mulch for fumigation, weed control, and soil cover has become the standard for production of many vegetables in the southeastern United States. Most low density polyethylene mulch laid for spring vegetable production is followed by a second crop in the autumn and potentially a third crop the following spring. These succeeding vegetable crops can be transplanted directly into the existing low density polyethylene mulch covered beds formed prior to spring fumigation. This allows for multiple crop production using the same beds. This is done in order to minimize expenses associated with low density polyethylene mulch and drip tape irrigation, by distributing costs over multiple crops (Fig. 1).
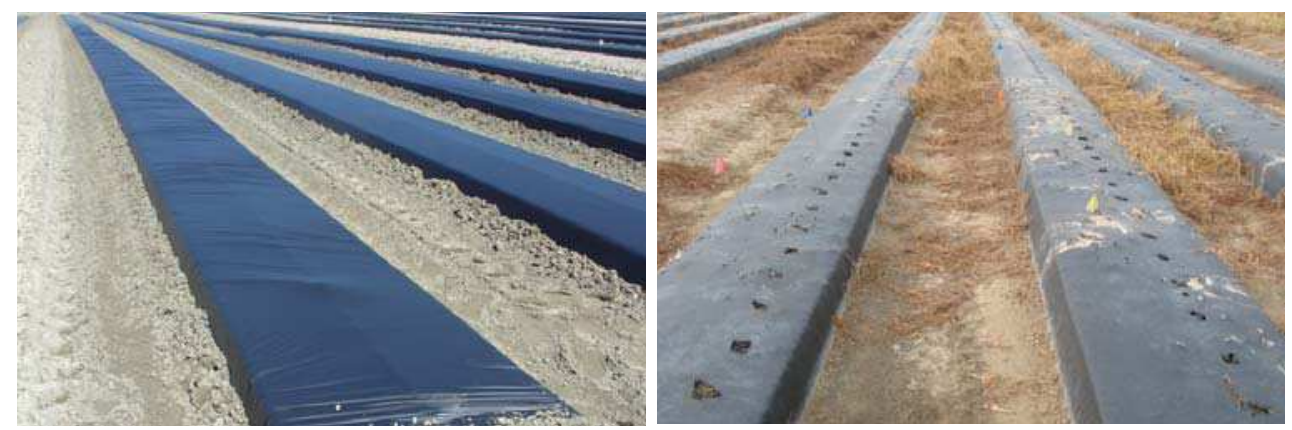

Fig. 1. Newly laid low density polyethylene mulch for spring planting of vegetables (left) and clean beds prior to autumn vegetable transplanting.

\section{Important}

Alternative methyl bromide fumigants have been investigated with varying levels of weed control success (Csinos et al., 2002; Webster et al., 2001; Gilreath et al., 2004). The major source of new herbicides for minor crops is the adaptation of herbicides registered for major crops. The process of registration of herbicides is expensive and time consuming for minor crops (Fennimore \& Doohan, 2008). Yellow nutsedge (Cyperus esculentus) and purple nutsedge (Cypresrotundus) are the most common and troublesome vegetable weeds in 
vegetables throughout the southern United States (Webster, 2006; Webster \& MacDonald, 2001). Even with polyethylene bed covers, nutsedge control in vegetable production is essential, as emerging shoots can grow though the cover (Adcock et al., 2008; Bullock, 1990; Locascio et al., 1994; Igbokwe, 1996; Stiles et al., 1999). Herbicides that could be soil incorporated into vegetable systems using low density polyethylene mulch must be effective on Cyperus species. Although extended residual control can be beneficial, it poses a threat to future crops (Johnson et al., 2010). If growers use the low density polyethylene mulch for multiple vegetable cropping systems, there is a potential for herbicide carryover to injury succeeding crops, which could increase, dependent on herbicide persistence (Johnson \& Mullinix, 2005). In previous studies, it was determined that pesticide dissipation was affected by polyethylene mulch, which could influence weed control, crop injury, and pesticide persistence. The dissipation of linuron, pendimethalin, chlorobromuron, and flurochloridone was reduced when applied to soil under perforated polyethylene covers verses bare soil (Bond \& Walker, 1989). Many vegetable producers in the southeastern United States often apply herbicides between crop plantings in order to destroy the previous crop and/or weed infestations (Gilreath et al., 2006). Herbicides that can be used between crops for low density polyethylene mulch vegetation control include glyphosate, paraquat, carfentrazone, and halosulfuron. Pesticides applied over the top of low density polyethylene mulch can leave residues on the mulch (Nerin et al., 1996). When herbicides are applied to the low density polyethylene mulch or row middles, and then when crops are transplanted soon afterwards, injury can occur (Culpepper et al., 2009; MacRae \& Culpepper, 2007; Gilreath \& Duranceau, 1986). The purpose of this chapter is to present current information about the chemical dissipation of herbicides used for vegetable production as alternatives to methyl bromide under different application scenarios.

\section{Information}

Herbicide dissipation is chemical and environmentally dependent. Soil incorporated herbicides are exposed to variable microbial, hydrolysis, soil $\mathrm{pH}$, organic matter, and other factors that may limit their activity. However, herbicide adsorption to soil colloids with subsequent hysteresis may extend activity and thus potential for either weed control or carryover to subsequent crops. Post emergence applied herbicide dissipation can be influenced by chemical properties such as water solubility, photo degradation, volatility, and environmental aspects such as rainfall and irrigation volumes, plant interception and absorption. While herbicide dissipation differs with respect to application method, many of the same factors influence fate in the environment.

\subsection{Soil applied herbicides}

Halosulfuron (Grichar et al., 2003; Nelson \& Renner, 2002; Vencill et al., 1995), sulfentrazone (Grichar et al., 2003; Wehtje et al., 1997), and metolachlor (Cornelius et al., 1985; Obrigawitch et al., 1980) provide soil residual activity on Cyperus species with control often extending for many weeks or months after applications. While these herbicides are viable alternatives to fumigation in vegetable production, they may cause injury to newly transplanted crops (Figure 2), and potential carryover issues to subsequent crops.

Dermiyati \& Yamamoto (1997a) indicated that halosulfuron adsorption was highly correlated with soil organic carbon content and inversely related to soil $\mathrm{pH}$. Degradation of halosulfuron increases with increasing temperature and lower soil $\mathrm{pH}$ but varied with soil moisture content and soil type (Dermiyati \& Yamamoto, 1997b). Halosulfuron degradation 


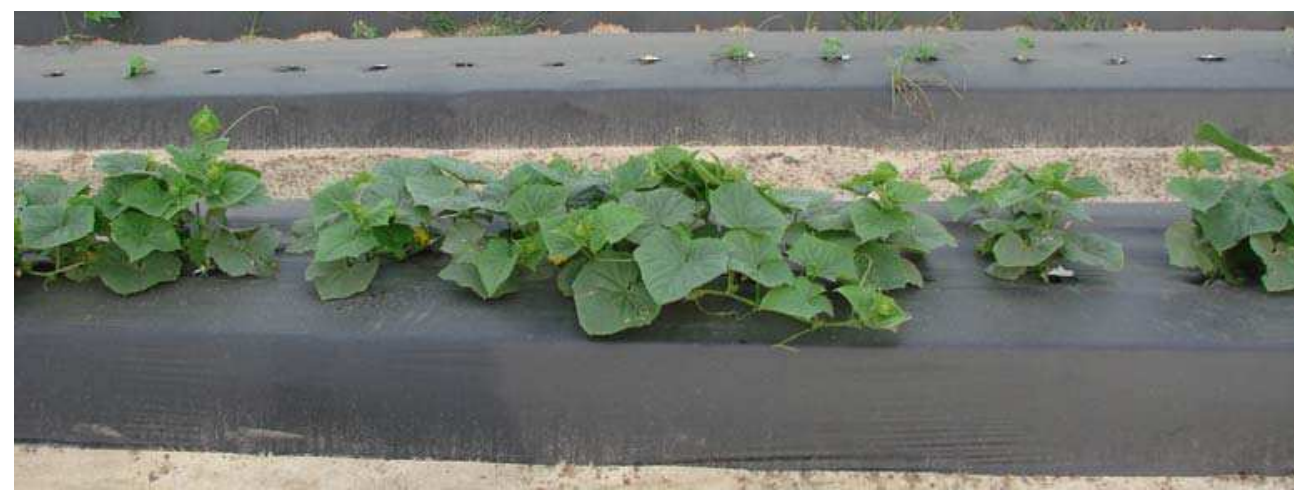

Fig. 2. Foreground: bed nontreated control transplanted cucumber; background bed herbicide injury on transplanted cucumber.

is primarily through chemical hydrolysis and microbial means. Carpenter et al. (1999) reported a positive relationship between organic matter and halosulfuron adsorption, that sorghum [Sorghum bicolor (L.) Moench] injury was less likely on soils with high organic matter content, and halosulfuron can exhibit soil hysteresis.

Metolachlor dissipation from soil has been extensively investigated (Bouchard et al., 1982; Braverman et al., 1986; Gaynor et al., 1993; Obrigawitch et al., 1981; Peter \& Weber, 1985; Weber et al., 2003). Weber et al. (2003) reported that metolachlor sorption, mobility, and soil retention was related to organic matter, clay content, and surface area. As soil organic matter concentration increases, adsorption of metolachlor increases. Metolachlor mobility was inversely related to soil organic matter and clay content. Other studies came to the same conclusions and also indicated that metolachlor binding was by physical forces between metolachlor molecules and soil constituent surfaces (Weber et al., 2003). Half-life of metolachlor varies with soil temperature, moisture, and organic matter content (Parker et al., 2005; Vencill, 2002 a).

Previous research indicated that the adsorption and mobility of sulfentrazone is $\mathrm{pH}$ and soil type-dependent (Grey et al., 1997) and that it does exhibit hysteresis (Grey et al., 2000). Reddy \& Locke (1998) confirmed the conclusion that sulfentrazone availability was both pH and soil series-dependent. They also concluded that sulfentrazone sorption was greater in no-till than in conventional tillage and attributed this to the higher organic matter content. Soil dissipation of sulfentrazone has varied with climatic factors. Ohmes et al. (2000) noted that sulfentrazone dissipation was slowed by dry soil conditions, leading to substantial residual activity in subsequent crops. There was little-to-no injury to rotational vegetable crops from sulfentrazone when it was applied in accordance to the product label (Garvey \& Monks, 1998). For the vegetable crops they investigated, all exhibited little to no adverse effects as part of a rotation with sulfentrazone. The residual effects of sulfentrazone on rotational cotton have been established with rates exceeding $0.4 \mathrm{~kg} \mathrm{ha}^{-1}$ applied the previous year (Main et al., 2004; Ohmes et al., 2000).

Persistence, dissipation, and degradation of halosulfuron (Kuwatsuka \& Yamamoto 1997a, 1997b), metolachlor (Gaynor et al., 1993, Parker et al 2005; Weber et al., 2003), and sulfentrazone (Grey et al., 1997, 2000; Ohmes et al., 2000; Reddy \& Locke, 1998) have been previously investigated in agronomic and/or vegetable soils. These investigations emphasized soil and/or organic cover scenarios in separate experiments. However, there is 
little information on these herbicides applied to bare-soil verses soil under polyethylene mulch situations (Figure 3).

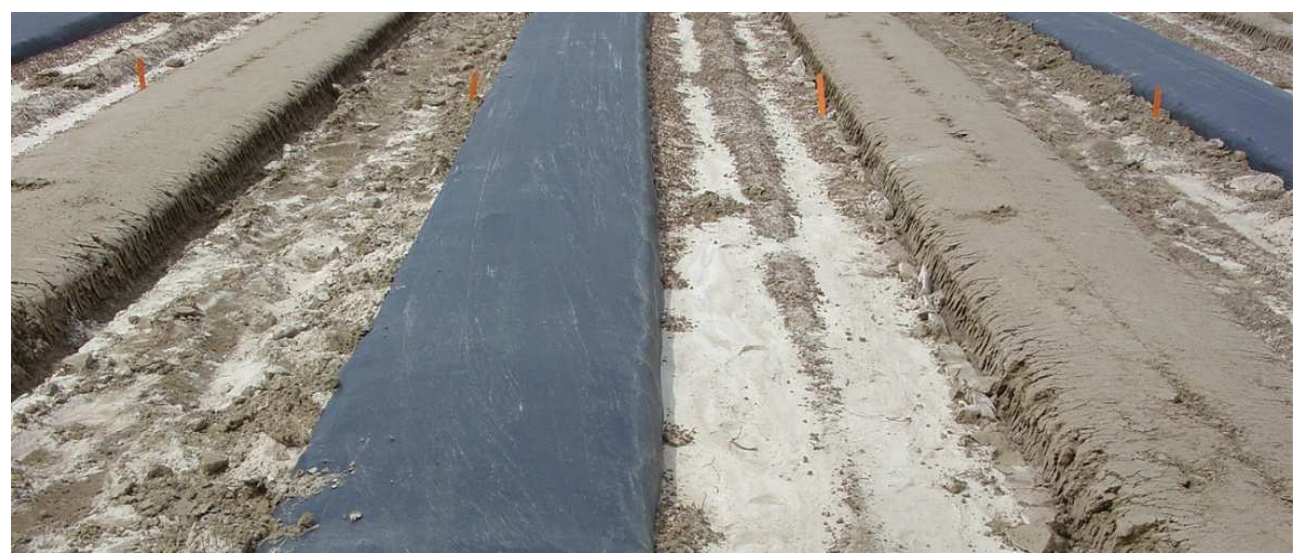

Fig. 3. Bare soil and soil covered with low density polyethylene mulch prepared for vegetable planting.

\subsection{Herbicides applied to low density polyethylene mulch}

Low density polyethylene mulch has permeability to fumigants via diffusion through the matrix (Papiernik \& Yates, 2001a; Papiernik \& Yates, 2001b). This occurs as the fumigant dissolves into the surface of the low density polyethylene mulch facing the soil, then diffusion through the film, and eventual evaporation from the opposite surface (Rogers, 1985). However, little information exists about low density polyethylene mulch adsorptive properties with respect to pesticides.

Previous research noted that paraquat dissipation from low density polyethylene mulch, when post emergence surface applied, was achieved by photo degradation (Gilreath et al., 2006; Gilreath \& Duranceau, 1986) or removal with an eluent such as water (Gilreath \& Duranceau, 1986). The persistence, dissipation, and degradation of paraquat from low density polyethylene mulch were evaluated using bioassays (Gilreath \& Duranceau, 1986) and colorimetric procedures (Gilreath et al., 2006). However, besides paraquat, few herbicides have been analytically quantified for dissipation from low density polyethylene mulch (Grey et al., 2009).

\subsection{Research}

These two factors, soil applied residual herbicides and herbicide residues remaining on low density polyethylene mulch, can potentially injure or kill vegetable crops in rotation. Understanding the impact of low density polyethylene mulch on residual herbicide soil dissipation when incorporated into vegetable production and the respective rotational issues will impact what herbicides, and crops, producers will apply and grow, respectively. Additionally the impact of dissipation of herbicides when surface applied to low density polyethylene mulch will impact which herbicides producers will utilize between vegetable crop plantings. The objectives were to review information which compares soil dissipation of residual herbicides in bare soil verses soil under low density polyethylene mulch, and 
herbicide dissipation from low density polyethylene mulch when topically applied, using field experiments and analytical chemical analysis.

\subsection{Field studies}

Field studies conducted to evaluate herbicide dissipation of herbicides had two distinct research objectives. However, all experiments were conducted similarly. Bed formation (20 $\mathrm{cm}$ raised bed), single drip irrigation tube, and lying of $32 u$ m-thick (1.25 mil) low density polyethylene mulchoccurred simultaneously. All studies were conducted on Tifton loamy sand (fine-loamy, kaolinitic, thermic PlinthicKandiudults) with 86 to $88 \%$ sand, $8 \%$ silt, 4 to $6 \%$ clay, 0.5 to $1.3 \%$ organic matter, and $\mathrm{pH}$ ranging from 6.3 to 6.9 .

\subsection{Soil dissipation research}

The first experiments evaluated herbicide dissipation for bare soils verses soil under low density polyethylene mulch. For the soil dissipation experiments, herbicide treatments included halosulfuron, $S$-metolachlor, and sulfentrazone applied at recommended rates for weed control for the region.Surface soil was sampled with a plugger-type sampler with four samples were collected to a depth of $8 \mathrm{~cm}$ from each plot and combined into a single sample. Soil cores were collected at 1 hour, 1, 2, 14, 27, and $56 \mathrm{~d}$ after treatment for one experiment and 1 hour, 1, 2, 3, 7, 14, 21, 28, 44, and 66 days after treatment in the second experiment.All samples were immediately frozen upon collection and stored at $-10 \mathrm{C}$ prior to analysis. For soil herbicide analysis, soils were thawed, air dried on a lab bench for 8 hours, passed through a 3-mm sieve, and then stored at $-10 \mathrm{C}$. Field plot replicate sample integrity was maintained throughout sample collection, preparation, and chemical analysis.

\subsection{Low density polyethylene mulch research}

For herbicide dissipation from the surface of low density polyethylene mulch experiments, dissipation was measured quantitatively using analytical techniques for two scenarios: under dry conditions (rain free and no irrigation) versus wash off using water as an eluent. Herbicide treatments included paraquat, glyphosate, carfentrazone, and halosulfuron. For the wash off studies, samples were collected at one hour after treatment, irrigated at three hours after treatment with one $\mathrm{cm}$ of water using an overhead irrigation system, then sampled again at five hours after treatment. This washing and sampling procedure was then repeated at 24, 48,72 and 96 hours after treatment. Samples were collected from each plot. Samples were then carefully stored in brown glass jars. For all studies, care was taken to prevent contamination between samples and to collect a representative sample from each plot. All samples were immediately frozen upon collection and stored at $-10 \mathrm{C}$ prior to analysis.

\subsection{Analytical herbicide quantification}

Herbicide analytical methods differ by chemical due to variation in solubility, structure, volatility, etc. Therefore, various methods are used to quantify. One common method is the use of high pressure liquid chromatography in tandem with mass spectrometry (HPLC-MS). This procedure allows for accurate measures for many different compounds at extremely sensitive levels of detection. Proper sample handling includes solvent identification, solvent ratios, extraction methods, injection volumes, and equipment settings. Herbicides and methods of analysis discussed for the purpose of this chapter, using HPLC-MS, are listed in Table 1. 


\begin{tabular}{|c|c|c|c|c|c|c|c|}
\hline Herbicide & Method & Mobile phase & Column & $\begin{array}{l}\text { Flow } \\
\text { rate }\end{array}$ & \begin{tabular}{|c|} 
Ion \\
monitoring
\end{tabular} & $\begin{array}{c}\text { Cone } \\
\text { voltage }\end{array}$ & $\begin{array}{c}\text { APCI } \\
/ \mathrm{ESI}\end{array}$ \\
\hline & & & & $\mathrm{ml} / \mathrm{min}$ & & $\mathrm{C}$ & $\mathrm{C}$ \\
\hline S-metolachlor & $\begin{array}{l}\text { LC-MS } \\
\text { SIR }\end{array}$ & $\begin{array}{c}\mathrm{ACN} 40 \% \\
\mathrm{MeOH} \text { with } \\
0.2 \% \text { acetic acid }\end{array}$ & Ymc ODS & 0.2 & $\begin{array}{c}\text { ESI } \\
\text { positive }\end{array}$ & 20 & 380 \\
\hline Sulfentrazone & $\begin{array}{l}\text { LC-MS } \\
\text { SIR }\end{array}$ & $\begin{array}{c}\text { ACN } 25 \% \\
\text { MeOH with } \\
0.2 \% \text { acetic acid }\end{array}$ & Ymc ODS & 0.2 & $\begin{array}{c}\text { ESI } \\
\text { negative }\end{array}$ & 51 & 370 \\
\hline Glyphosate & $\begin{array}{l}\text { LC-MS } \\
\text { SIR }\end{array}$ & $\begin{array}{l}\text { ACN } 50 \mathrm{mM} \\
\text { ammonium } \\
\text { acetate }\end{array}$ & $\begin{array}{c}\text { Phenomene } \\
\text { x C18 }\end{array}$ & 0.7 & $\begin{array}{c}\text { APCI } \\
\text { positive }\end{array}$ & 100 & 475 \\
\hline Paraquat & $\begin{array}{c}\text { LC-MS } \\
\text { SIR }\end{array}$ & $\begin{array}{c}\text { 60:40 ACN } \\
\text { Buffer pH } 4.5\end{array}$ & Waters Si & 0.4 & $\begin{array}{c}\text { ESI } \\
\text { negative }\end{array}$ & 41 & 380 \\
\hline Halosulfuron & $\begin{array}{c}\text { LC-MS } \\
\text { SIR }\end{array}$ & $\begin{array}{c}\text { ACN } 10 \% \\
\text { MeOH with } 0.1 \\
\text { ml ammonium } \\
\text { hydroxide }\end{array}$ & ymc ODS & 0.2 & $\begin{array}{c}\text { ESI } \\
\text { negative }\end{array}$ & 32 & 370 \\
\hline Carfentrazone & $\begin{array}{c}\text { LC-MS } \\
\text { SIR }\end{array}$ & $\begin{array}{c}\text { ACN } 10 \mathrm{MeOH} \\
\text { with } 10 \mathrm{mM} \\
\text { formic acid }\end{array}$ & ymc ODS & 0.2 & $\begin{array}{c}\text { ESI } \\
\text { positive }\end{array}$ & 23 & 350 \\
\hline Flumioxazin & $\begin{array}{c}\text { LC- } \\
\text { MSMRM }\end{array}$ & $\begin{array}{c}\mathrm{ACN} 1.25 \mathrm{mM} \\
\text { TDFHA }\end{array}$ & $\begin{array}{l}\text { Hypersil } \\
\text { ODS }\end{array}$ & 0.6 & $\begin{array}{c}\text { APCI } \\
\text { positive }\end{array}$ & 40 & 484 \\
\hline
\end{tabular}

Table 1. Analytical methods for herbicide dissipation studies.

\subsection{Herbicide dissipation kinetics}

Herbicide dissipation data are often described by non-linear regression in addition to analysis of variance for the specific test. The intent is to determine if the responses can be described by using the exponential decay equation

$$
y=B_{o} \mathrm{e}^{-B_{1}(x)}
$$

where $y$ is herbicide concentration, $B_{0}$ is the initial concentration, $B_{1}$ is dissipation rate, and $x$ is time in hours or days after treatment. After data is regressed against time, the output from the analysis includes first-order dissipation rate constant (k) (Ohmes et al., 2000). All data by herbicide for the exponential decay equations can be subjected to analysis of variance (ANOVA) using the general linear models procedures with mean separation using $95 \%$ asymptotic confidence intervals. Dissipation time (50\%) is then determined using the equation

$$
\mathrm{DT}_{50}=\ln 0.50 / \mathrm{k}
$$

(Dermiyati \& Yamamoto, 1997b; Lui et al., 2002; Mueller et al., 1999). Data are then often presented with graphics software. 


\subsection{Herbicide dissipation research}

For the following research information, all experiments were conducted at times when herbicide applications could potentially occur in the south-eastern vegetable production regions of the United States and are thus representative of producer practices.

\subsection{Soil dissipation research}

The exponential decay equation [1] effectively describes halosulfuron dissipation (Figure 3). First-order dissipation rate constants (k) for halosulfuron were less (i.e. slower dissipation) for soil under low density polyethylene mulch (0.07) than for bare soil (0.10). Halosulfuron dissipation for bare soil dropped to undetectable levels by 27 and 28 days after treatment in two studies, respectively. This trend was similar for soil under low density polyethylene mulch. From equation [2], the $\mathrm{DT}_{50}$ for bare-soil was 6 to 7 daysverses soil under low density polyethylene mulch which was 10 days. Although the first-order rate constants were not significantly different between bare soil and soil under LDPE mulch, the $\mathrm{DT}_{50}$ was 3 to 4 days longer for soil under low density polyethylene mulch. Dermiyati and Yamamoto (1997b) reported halosulfuron half-lives of 7 to 98 days depending on soil moisture and temperature regimes.

$S$-metolachlor dissipation was well described by the exponential decay equation [1] and for bare soil and soil under low density polyethylene mulch (Figure 3). First-order dissipation rate constants for $S$-metolachlor were less for soil under low density polyethylene mulch (0.2) than for bare soil (0.4). S-metolachlor dissipation was rapid for bare soil and soil under low density polyethylene mulch dropping to undetectable levels by 44 days after treatment. Rapid dissipation has been previously noted for metolachlor with sandy soil under moist soil conditions (Weber et al., 2003). In one experiment, S-metolachlor dissipation was biphasic, dropping to less than $400 u \mathrm{~g} / \mathrm{kg}$ of soil at 7 days after treatment, yet was detectable at 44 days after treatment for both soil scenarios. While the $\mathrm{DT}_{50 \mathrm{was}} 2$ and 5 days for bare soil and soil under low density polyethylene mulch, respectively, dissipation was slower in one year as compared to another. This could be attributed to an equilibrium that was reached with $S$-metolachlor where soil adsorption had occurred, and then desorption of the parent was observed over time (Patakioutas \& Albanis 2002). Data indicated that low density polyethylene mulch decreased the rate of dissipation of $S$-metolachlor versus bare soil which could extend its herbicidal activity.

Sulfentrazone dissipation varied but was slower than halosulfuron and S-metolachlor (Figure3) and had the longer $\mathrm{DT}_{50}$. Overall, the exponential decay equation [1] adequately described the sulfentrazone dissipation. Sulfentrazone dissipation first order rate constants were equal on average, with 0.055 for soil under low density polyethylene mulch and 0.050 for bare-soil. Half-lives were 16 days for bare-soil and 13 days for soil under low density polyethylene mulch. While counter intuitive, this could be due to increased temperature regimes that have been noted under polyethylene mulch (Peachey et al., 2001), that could have accelerated dissipation. Ohmes et al. (2000) previously noted that sulfentrazone dissipation followed first-order kinetics in Tennessee soils. They reported varying dissipation with $\mathrm{DT}_{50}$ ranging from 24 to 118 days. Variation in sulfentrazone $\mathrm{DT}_{50}$ has been noted from 2 (Collins et al., 1999) to 302 days (Vencill, 2002 b).

These studies indicate that halosulfuron-methyl and $S$-metolachlor dissipation was more rapid for bare-soil than soil under low density polyethylene mulch. However, sulfentrazone dissipation was variable. For bare-soil and soil covered with low density polyethylene mulch, dissipation of halosulfuron and $S$-metolachlor were biphasic (Figure 3). 

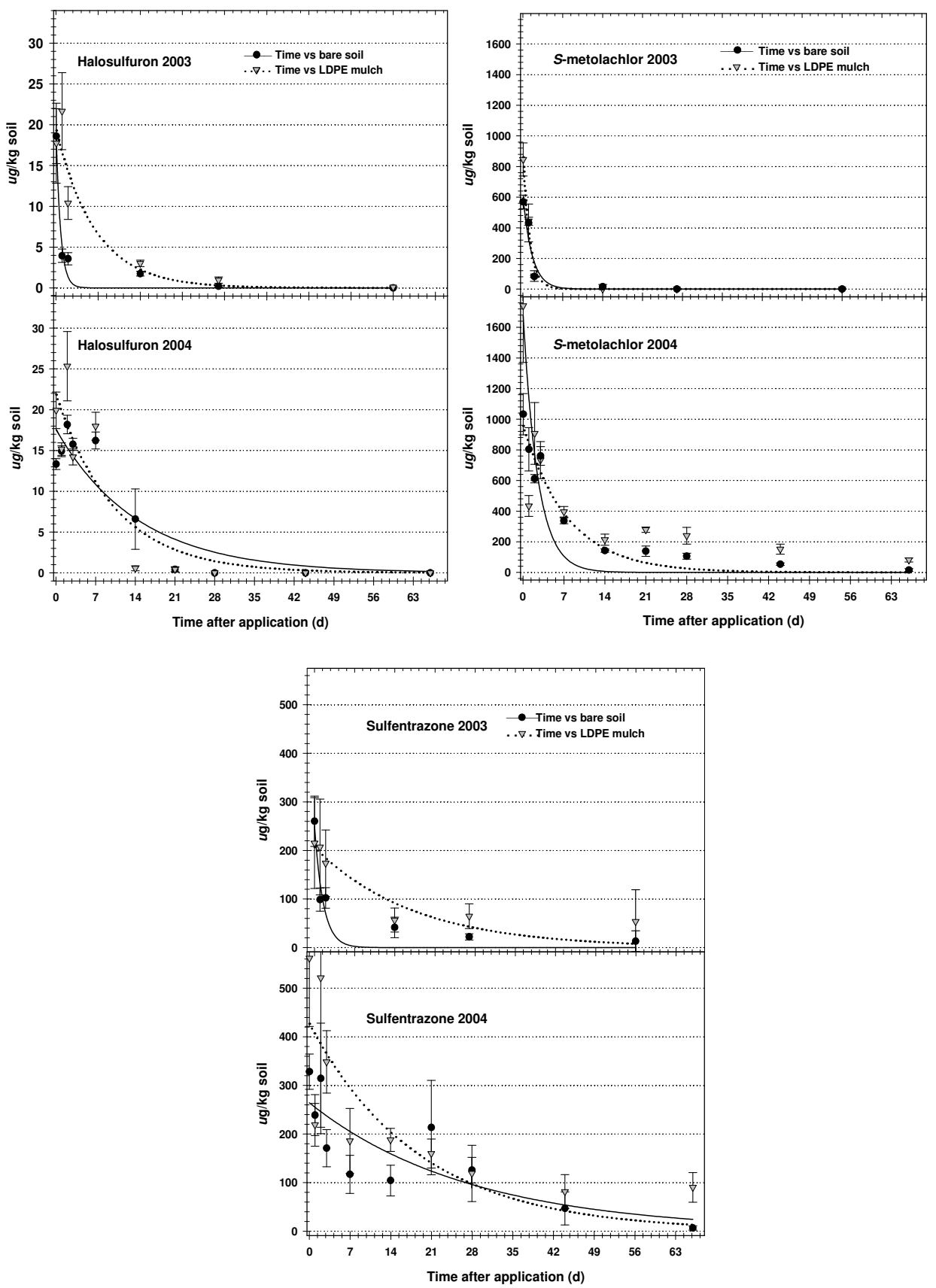

Fig. 3. Halosulfuron, s-metolachlor, and sulfentrazone dissipation for bare soil and soil covered with low density polyethylene mulch. 
Sulfentrazone dissipation was slower (Figure 3) than halosulfuron or metolachlor. This indicates that sulfentrazone could provide residual Cypress species control when preemergence applied to vegetables but could also result in carryover problems to subsequent plantings.
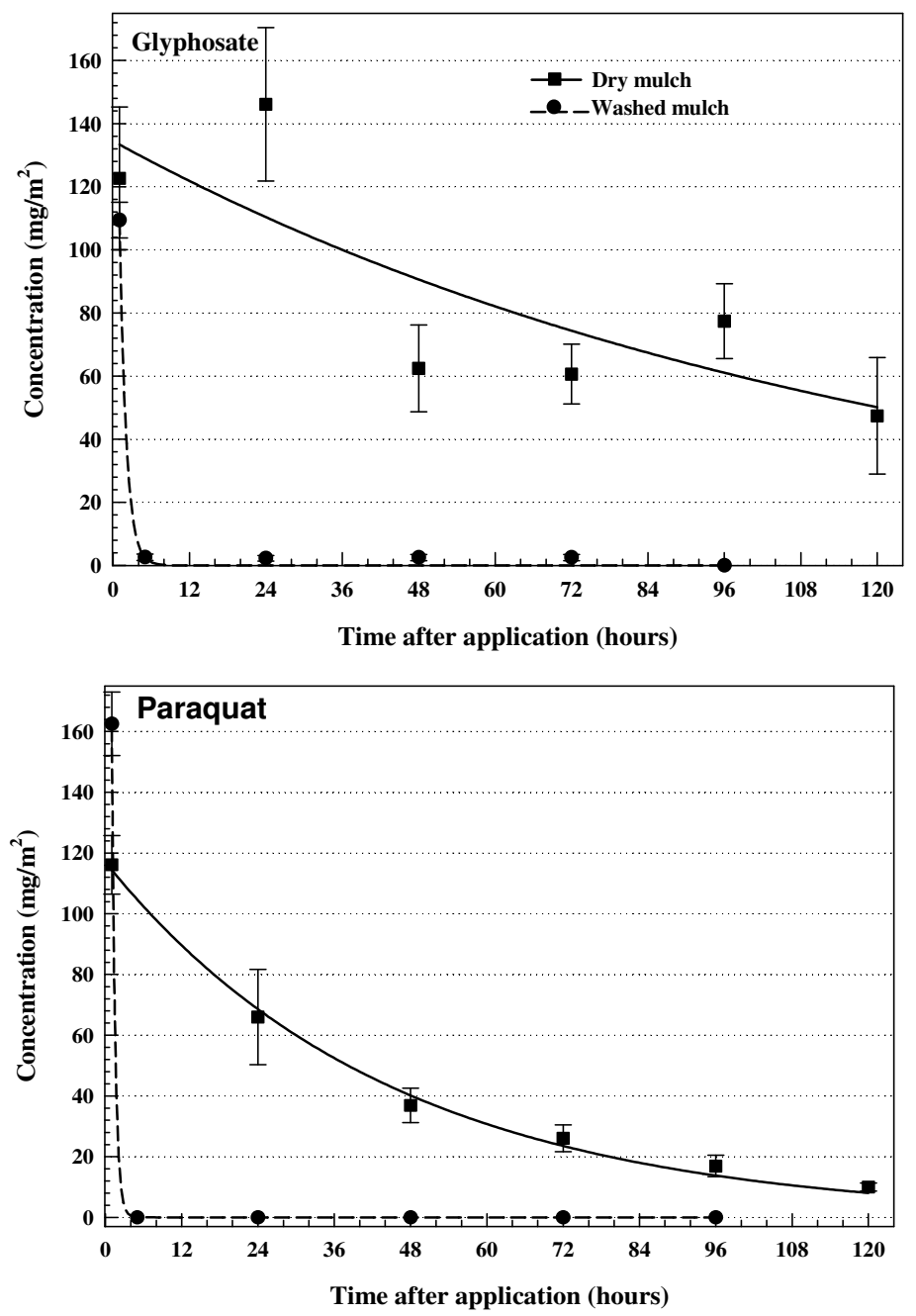

Fig. 4. Glyphosate and paraquat dissipation from low density polyethylene mulch for dry and wash off conditions over time.

\section{2 Low density polyethylene dissipation research}

The exponential decay equation [1] effectively described dry and irrigated glyphosate dissipation (Figure 4). First-order dissipation rate constants $(k)$ for glyphosate were (i.e. slower dissipation) less for the dry study at 0.008 than for the irrigated study at 0.933 . For 
glyphosate, $\mathrm{DT}_{50}$ for the dry study was 84 hours, while it was 1 hour in the irrigated experiment. Glyphosate concentration dropped to less than $5 \mathrm{mg} / \mathrm{m}^{2}$ levels by the 2nd irrigation event at 24 hours after treatment. Glyphosate dropped to undetectable levels by the $5^{\text {th }}$ irrigation at 96 hours after treatment when greater than $4 \mathrm{~cm}$ of water had been applied. Glyphosate has negligible photo degradation losses, is tightly adsorbed to soil, and high water solubility (Senseman, 2007). Glyphosate adsorption to clay minerals is $\mathrm{pH}$ dependent and fluctuations can occur, depending upon the type of soil saturating cation (McConnell \& Hossner, 1985). In contrast to the wash off experiments, glyphosate dissipation from low density polyethylene mulch for the dry study was linear and 50 $\mathrm{mg} / \mathrm{m}^{2}$ remaining 120 hours after treatment. For the dry study there was an 84 hour halflife for glyphosate, and it would require at least $28 \mathrm{~d}$ (eight half-lives) to reach less than 1 $\mathrm{mg} / \mathrm{m}^{2}$ on the mulch. Glyphosate can be persistent in low density polyethylene mulch as reported by Gilreath \& Santos (2004). For their bioassay study with tomato (Lycopersiconesculentum L.) in a dry study, they indicated there was enough glyphosate remaining 16 days after application to reduce fresh plant weight by $73 \%$.

First order rate dissipation constants for paraquat were significantly different for the irrigated (1.88) and dry studies (0.022). Paraquat is a cationic dichloride salt with a water solubility of $620,000 \mathrm{mg} / \mathrm{L}^{1}$ (Senseman, 2007). After the $1^{\text {st }}$ irrigation application of $1 \mathrm{~cm}$ of water, paraquat was undetectable on the mulch (Figure 4), which was further demonstrated with a 1 hour $\mathrm{DT}_{50}$. Given the high water solubility of paraquat, rapid dissipation will occur with water. As previously noted, paraquat dissipation can also occur via photo degradation (Senseman, 2007). With each subsequent 24 hour sampling period, paraquat dissipation was reduced step-wise, falling to $10 \mathrm{mg} / \mathrm{m}^{2}$ at 120 hours after treatment (Figure 2) with a DT 50 of 32 hours for the dry study. Gilreath et al. (2006) reported similar findings for paraquat on low density polyethylene mulch using a colorimetric analysis procedure.

The exponential decay equation [1] described halosulfuron dissipation for the dry scenario with a first order rate constant of 0.038 . In the irrigated study, however, the exponential decay equation did not accurately describe halosulfuron dissipation from low density polyethylene mulch, and actually under estimated the levels detected (Figure 5). Halosulfuron dissipation for the irrigated study appeared to be biphasic, with an initial rapid decline, and then little to no removal with each subsequent irrigation event. The first phase of halosulfuron dissipation is chemical hydrolysis and is abiotic in nature, whereas the second phase is microbial dependent. This would explain the biphasic nature for observed dissipation with irrigation. Halosulfuron dissipation in the irrigated study had first order rate constant of 0.24 , which was significantly higher than that in the dry study. Halosulfuron is a weak acid with negligible photo-degradation losses (Senseman 2007). Halosulfuron has exhibited hysteresis in higher organic matter Japanese soils (Dermiyati \& Yamamoto, 1997a). Given this previously noted hysteric soil affect, it is suspected halosulfuron is behaving similarly when applied to low density polyethylene LDPE mulch. Halosulfuron dissipation was linear and varied by less than $1.1 \mathrm{mg} / \mathrm{m}^{2}$ from initial application with $3.5 \mathrm{mg} / \mathrm{m}^{2}$ at 1 hour after treatment to $2.4 \mathrm{mg} / \mathrm{m}^{2} 120$ hours after treatment for the dry study.

Dissipation of carfentrazone was well described by the exponential decay equation [1] with first order rate constants of 0.023 and 0.025 and $\mathrm{DT}_{50}$ values of 30 and 28 hours for the dry and wash off studies, respectively. Sampling of the dry and irrigation studies indicated nearly identical dissipation curves (Figure 5). Initial carfentrazone concentrations on the low density polyethylene mulch were 7.8 to $8.4 \mathrm{mg} / \mathrm{m}^{2}$ at 1 hour after treatment. With each 
subsequent sampling at 24, 48, 72, and 96 hours after treatment, carfentrazone concentrations did not differ by more than $0.4 \mathrm{mg} / \mathrm{m}^{2}$ for samples of the dry and wash off low density polyethylene mulch. Carfentrazone water solubility is $12,000 \mathrm{mg} / \mathrm{L}^{1}$ and increases with temperature; it does not photo-degrade, is non-volatile, is not adsorbed to soil, but it is broken down via microbial break down (Senseman, 2007).
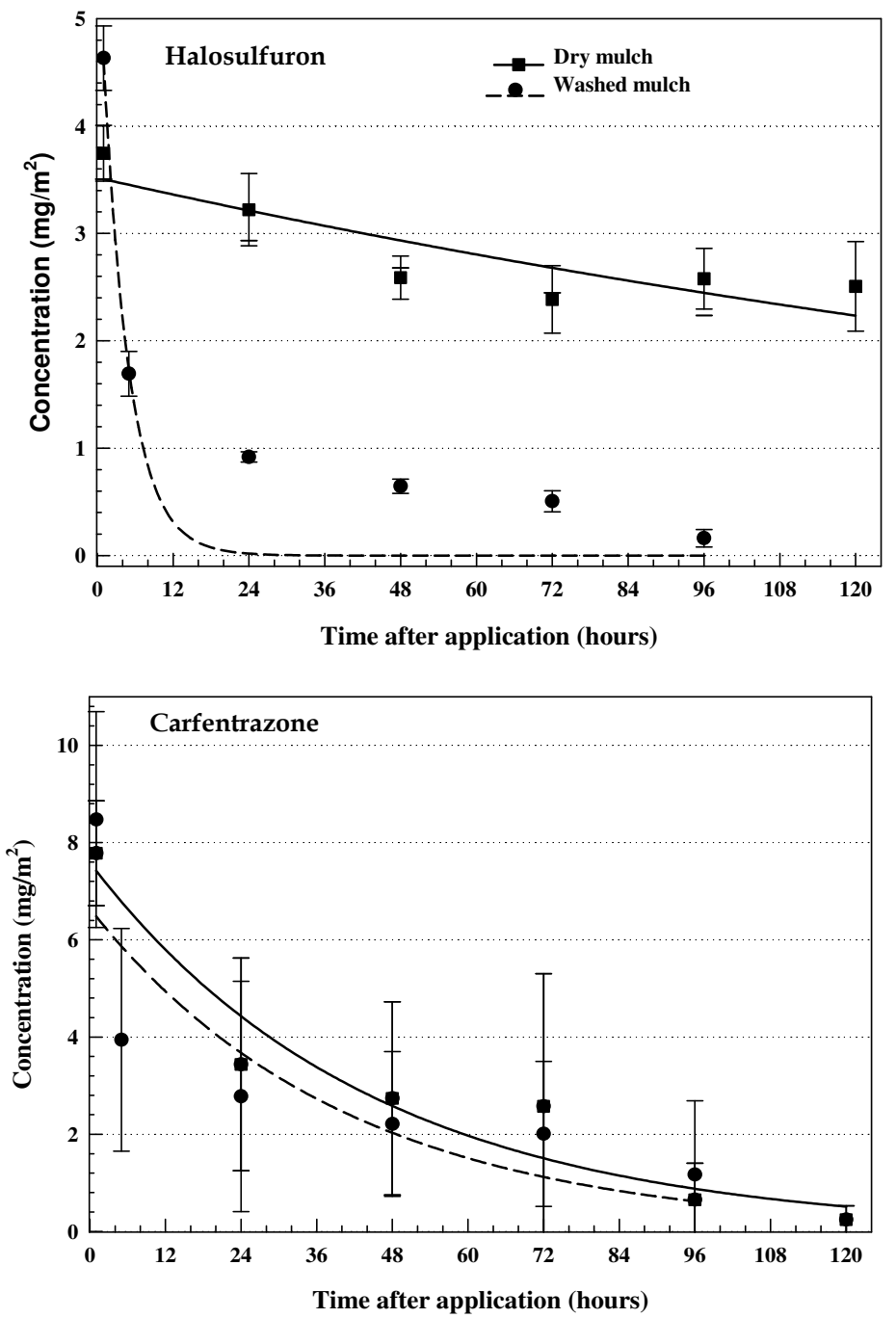

Fig. 5. Halosulfuron and carfentrazone dissipation from low density polyethylene mulch for dry and wash off conditions over time.

These studies indicate that glyphosate and paraquat dissipation was rapid from low density polyethylene mulch when irrigation water was used as a solvent. Halosulfuron and carfentrazone were detectable even after five wash off events, indicating some type of 
adsorption, or physical trapping within the matrix, maybe occurring with the low density polyethylene mulch, with subsequent release with each wash off event (Figures 4 and 5).

\section{Conclusions}

Herbicides will be an alternative to fumigants for weed control in low density polyethylene mulch vegetable production. However, given the persistent chemical nature of some herbicides, care must be taken in planning potential rotational crops to prevent any soil carryover issues that could injury or kill sensitive species. S-metolachlor soil dissipation data indicated it was less likely to persist than halosulfuron or sulfentrazone. These studies indicated that halosulfuron-methyl and $S$-metolachlor dissipation was more rapid for baresoil than soil under low density polyethylene mulch.

Glyphosate and paraquat can be quickly dissipated by water when these herbicides are applied to the surface of low density polyethylene mulch. Carfentrazone and halosulfuron tended to adsorb to the mulch, increasing the potential for transplant injury. Glyphosate, paraquat, halosulfuron, and carfentrazone were all detectable at efficacious levels on the low density polyethylene mulch at 120 hours after treatment for the dry studies. These studies indicate that producers must be very conscious of the contact herbicide they apply between crops in low density polyethylene mulch production. They must also understand that using water as a dissipation mechanism may not totally remove the potential for herbicide injury to vegetable transplants, that failure to do so could result in significant plant injury and potential crop failure.

\section{References}

Adcock, C.W., Foshee III, W.G., Wehtje, G.R., \& C.H. Gilliam. (2008). Herbicide combinations in tomato to prevent nutsedge (Cyperus esulentus) punctures in plstic mulch for multi-cropping systems. Weed Technology. Vol 22:136-141.

Bond, S. \& Walker, A. (1989).Aspects of herbicide activity and persistence under low level polyethylene covers.Annals Applied BiologyVol. 114:133-140.

Bouchard, D.C., Lavy, T.L., \& Marx, D.C. (1982). Fate of metribuzin, metolachor, and fluometuron in soil. Weed Science Vol. 30:629-632.

Braverman, M.P., Lavy, T.L., \& Barnes, C.J. (1986). The degradation and bioactivity of metolachlor in the soil. Weed Science Vol. 34:479-484.

Bullock, F.D. (1990). Weed control. Commercial pepper production. Cooperative Extension Service, The University of Georgia College of Agriculture and Environmental Science, Athens, Ga. p 3-5.

Carpenter, A.C., Senseman, S.A., \& Cralle, H.T. (1999). Adsorption-desorption of halosulfuron on selected Texas soils, Proceedings of Southern Weed Science Society, Greensboro, NC. p. 211

Csinos, A.S., Webster, T.M., Sumner, D.R., Johnson, A.W., Dowler, C.C., \& Seebold, K.W. (2002). Application and crop safety parameters for soil fumigants. Crop Protection. Vol. 21:973-982.

Cornelius, A.J., Meggitt, W.F., \& Penner, D. (1985). Activity of acetanilide herbicides on yellow nutsedge (Cyperus esculentus). Weed Science. Vol. 33:721-723. 
Culpepper, A. S., Grey, T.L., \& Webster, T.M. (2009). Vegetable response to herbicides applied to low density polyethylene mulch prior to transplant. Weed Technology. Vol. 23:444-449.

Dermiyati, S.K. \& Yamamoto, I. (1997a). Degradation of the herbicide halosulfuron-methyl in two soils underdifferent environmental conditions. Journal of Pesticide Science. Vol. 22:282-287.

Dermiyati, S.K. \& Yamamoto, I. (1997b). Relationships between soil properties and sorption behavior of the herbicide halosulfuron-methyl in selected Japanese soils. Journal of Pesticide Science. Vol. 22:288-292.

Fennimore, S.A. and Doohan, D.J. (2008). The challenges of specialty crop weed control, future directions. Weed Technology.Vol 22:364-372.

Garvey, P.V. \& Monks, D.W. (1998). Response of vegetable crops grown in rotation to sulfentrazone treated soybeans, Proceedings of Southern Weed Science Society, Atlanta, GA.pp 91-92.

Gaynor, J.D., Hamill, A.S., \& MacTavish, M.C. (1993). Efficacy, fruit residues, and soil dissipation of the herbicide metolachlor in processing tomato. Journal of American Society Horticulture Science. Vol. 118:68-72.

Gilreath, J. P. \& Duranceau, S.J. (1986). Photodegradation of paraquat applied to polyethylene mulch film. Horticulture Science. Vol. 21:1145-1146.

Gilreath, J. P., Santos, B.M., \& Duranceau, S.J. (2006). Seasonal variation of paraquat photodegradation rate on polyethylene mulch. Weed Technology. Vol. 20: 315-318.

Gilreath, J.P. \& Santos, B.M. (2004). Bioassys on glyphosate residue toxicity and photodegradation on polyethylene mulch, Soil and Crop Science Society of Florida Proceedings, Tallahassee, FL.Vol. 63:21-24.

Gilreath, J.P., Noling, J.W., \& Santos, B.M. (2004). Methyl bromide alternatives for bell pepper (Capsicum annuum) and cucumber (Cucumissativus) rotations. Crop Protection.Vol. 23:347-351.

Grey, T.L., Bridges, D.C., \& NeSmith, D.S. (2002). Transplanted pepper (Capsicum annum) tolerance to selected herbicides and method of application. Journal of Vegetable Crop Protection.Vol. 8:27-39.

Grey, T.L., Culpepper, A.S., \& Webster, T.M. (2007). Fall vegetable response to herbicidesspring applied under polyethylene mulch. Weed Technology. Vol. 21:496500.

Grey, T. L., Vencill, W.K., Webster, T.M. \& Culpepper, A.S. (2009). Herbicide dissipation from low density polyethylene mulch. Weed Science. Vol. 57:351-356.

Grey, T.L., Walker, R., Wehtje, G.R., Adams Jr., J., Kwon, O., Weete, J., Dayan, F., \& Hancock, H.G. (2000). Behavior of sulfentrazone with ionic exchange resins, electrophoresis gels, \& cation-saturated soils. Weed Science. Vol. 48:239-247.

Grey, T.L., Walker, R.H., Wehtje, G.R., \& Hancock, H.G. (1997). Sulfentrazone adsorption andmobility as affected by soil and pH.Weed Science. Vol. 45: 733-738.

Grichar, W.J., Besler, B.A., \& Brewer, K.D. (2003). Purple nutsedge control and potato (Solanumtuberosum) tolerance to sulfentrazone and halosulfuron. Weed Technology. 17:485-490. 
Igbokwe, P.E., Tiwari, S.C., Collins, J.B., \& Russell, L.C. (1990). Herbicides for weed control field-grown peppers.Journal of Mississippi Academy of Science.Vol. 35:27-29.

Johnson III, W.C., Grey, T.L., \& Kissel, D.E. (2010). Interactive effects of soil pH, halosulfuron rate, and application method on carryover to turnip green and cabbage. Weed Technology. Vol24:160-164.

Johnson III, W.C. \& Mullinix, Jr. B.G. (2005). Effect of herbicide application method on weed management and crop injury in transplanted cantaloupe production. Weed Technology. Vol. 19:108-112.

Kuwatsuka, S.S. \& Yamamoto, I. (1997a). Degradation of the herbicide halosulfuron-methyl in two soils under different environmental conditions. Journal of Pesticide Science.Vol. 22:282-287.

Kuwatsuka, S.S. \& Yamamoto, I.(1997b). Relationships between soil properties and sorption behavior of the herbicide halosulfuron-methyl in selected Japanese soils. Journal of Pesticide Science.Vol. 22:287.

Lacascio, S.J., Dickson, S.W., \& Kuchare, T.A. (1994). Evaluation of multi-purpose soil fumigants for root-knot nematode and soilborne disease management on tomato in Florida. Proceedings Annual International Research Conference on Methyl Bromide Alternatives and Emission Reductions, Orlando, FL. p. 3

MacRae, A.W. \& Culpepper, A.S. (2007). Weed management update for cantaloupe, cucumber, squash, and watermelon, Proceedings of 2007 Southeast Regional Vegetable Conference, Savannah, GA. p. 50.

McConnell, J.S. \& Hossner, L.R. (1985). pH-dependent adsorption isotherms of glyphosate.Journal of Agriculture Food Chemistry.Vol33:1075-1076.

Main, C. L., Mueller, T.C., Hayes, R., Wilcut, J., Peeper, T., Talbert, R., \& Witt, W.W.(2004). Sulfentrazone persistence in southern soils: bioavailable concentration and effect on a rotational cotton crop. Weed Technology. Vol. 18:346-352.

Mueller, T.C., Shaw, D.R. \& Witt, W.W. (1999). Relative dissipation of acetochlor, alachlor, metolachlor and SAN 582 from three surface soils. Weed Technology. Vol. 13: 341346.

Nelson, K.A. \& Renner, K.A. (2002). Yellow nutsedge (Cyperus esculentus) control and tuberproduction with glyphosate and ALS-inhibiting herbicides. Weed Technology. Vol. 16:512-519.

Nerin, C., Tornes, A.R., Domeno, C. \& Cacho, J. (1996). Absorption of pesticides on plastic films used as agricultural soil covers. Journal of Agriculture and Food Chemistry.Vol. 44:4009-4014.

Obrigawitch, T., Abernathy, J.R., \& Gipson, J.R. (1980). Response of yellow (Cyperus esculentus) and purple (Cyperus rotundus) nutsedge to metolachlor. Weed Science. Vol. 28:708-715.

Obrigawitch, T., Hons, F.M., Abernathy, J.R., \& Gipson, J.R. (1981). Adsorption, desorption, and mobility of metolachlor in soils. Weed Science. Vol. 29:332-336.

Ohmes, G.A., Mueller, T. \& Hayes, R. (2000). Sulfentrazone dissipation in a Tennessee soil. Weed Technology. 14:100-105.

Papiernik, S.K. \& Yates, S.R. (2001a). Transport of fumigant compounds through HDPE and virtually impermeable films, Annual International Research Conference on Methyl 
Bromide Alternatives and Emissions Reductions Conference Proceedings: pp. 16-1 to 16-3 online at http://mbao.org/2001proc/mbrpro01.html.

Papiernik, S.K. and S.R. Yates. 2001b. An approach for estimating the permeability of agricultural films. Environmental Science Technology.Vol. 35:1240 -1246.

Parker, D.C., Simmons, F.W. \& Wax, L.M. (2005). Fall and early preplant application timing effects on persistence and efficacy of acetamide herbicides. Weed Technology. Vol. 19:6-13.

Patakioutas, G. \& Albanis, T.A. (2002). Adsorption-desorption studies of alachlor, metolachlor, EPTC, chlorothalonil and pirimiphos-methyl in contrasting soils. Pest Management Science.Vol. 58:352-362.

Peachey, R.E., Pinkerton, J.N., Ivors, K., Miller, M. \& Moore, L. (2001). Effect of soil solarization, cover crops, and metham on field emergence and survival of buried annual bluegrass (Poaannua) seeds. Weed Technology. Vol. 15:81-88.

Peter, C.J. \& Weber, J.B. (1985). Adsorption, mobility, and efficacy of alachlor, and metolachlor as influenced by soil properties. Weed Science. Vol. 33:874-881.

Reddy, K.N. \& Locke, M.A. (1998). Sulfentrazone sorption, desorption, and mineralization insoils from two tillage systems. Weed Science. Vol. 46:494-500.

Rogers, C.E. 1985. Permeation of gases and vapors in polymers. In Comyn, J. (ed.), Polymer Permeability,Elevier: London, England.pp11-73.

Senseman, S.A. 2007. Herbicide Handbook.9th edition, Weed Science Society of America,Champaign, IL.

Stiles, C.L., Coffey, D.L., \& Mueller, T.C. (1999). Yellow nutsedge control and tomato injury as affected by the interaction of vapam and the herbicides eptam, tillam, and matrix. Proceedings of Southern Weed Science Society. Greensboro, NC. pp82-83.

Vencill, W.K., Richburg III, J.S.,Wilcut, J.W., \& Hawf, L.R. (1995). Effect of MON-12037 onpurple (Cyperus rotundus) and yellow (Cyperus esculentus) nutsedge. Weed Technology. Vol. 9:148-152.

Vencill, W. K. (2002a). Herbicide Handbook.8th edition, Weed Science Society of America, Champaign, IL.pp 299-300.

Vencill, W. K. (2002b). Herbicide Handbook.8th edition, Weed Science Society of America, Champaign, IL.pp. 405-406.

Weber, J.B., McKinnon, E.J. \& Swain, L.R. (2003). Sorption and mobility of ${ }^{14}$ C-labeled imazaquin and metolachlor in four soils as influenced by soil properties. Journal of Agriculture Food Chemistry. Vol. 51:5752-5759.

Webster, T.M. (2006). Weed survey-southern states: vegetable, fruit and nut crops subsection.Proceedings of Southern Weed Science Society.San Antonio, TX. pp 260277.

Webster, T.M., Culpepper, A.S., \& JohnsonIII, W.C. (2003). Response of squash and cucumbercultivars to halosulfuron. Weed Technology. Vol. 17:173-176.

Webster, T.M., Csinos, A.S., Johnson, A.W., Dowler, C.C., Sumner, D.R. \& Fery, R.L.(2001). Methyl bromide alternatives in a bell pepper-squash rotation. Crop Protection. Vol. 20:605-614. 
Webster, T.M. \& MacDonald, G.E.(2001). A survey of weeds in various crops in Georgia. Weed Technology. Vol. 15:771-790.

Wehtje, G.R., Walker, R.H., Grey, T.L., \&Hancock, H.G.(1997). Response of purple (Cyperus rotundus) and yellow (Cyperus esculentus) nutsedges to selectiveplacement of sulfentrazone. Weed Science. Vol. 45:382-387. 


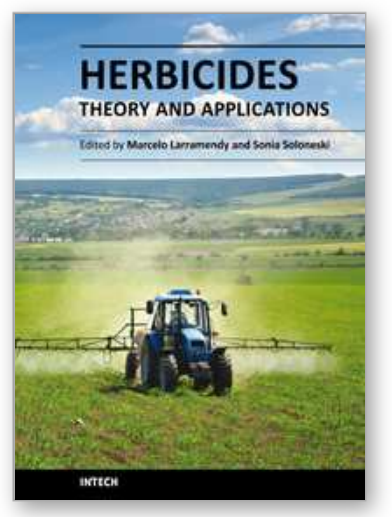

\author{
Herbicides, Theory and Applications \\ Edited by Prof. Marcelo Larramendy
}

ISBN 978-953-307-975-2

Hard cover, 610 pages

Publisher InTech

Published online 08, January, 2011

Published in print edition January, 2011

The content selected in Herbicides, Theory and Applications is intended to provide researchers, producers and consumers of herbicides an overview of the latest scientific achievements. Although we are dealing with many diverse and different topics, we have tried to compile this "raw material" into three major sections in search of clarity and order - Weed Control and Crop Management, Analytical Techniques of Herbicide Detection and Herbicide Toxicity and Further Applications. The editors hope that this book will continue to meet the expectations and needs of all interested in the methodology of use of herbicides, weed control as well as problems related to its use, abuse and misuse.

\title{
How to reference
}

In order to correctly reference this scholarly work, feel free to copy and paste the following:

Timothy Grey and William Vencill (2011). Residual Herbicide Dissipation in Vegetable Production, Herbicides, Theory and Applications, Prof. Marcelo Larramendy (Ed.), ISBN: 978-953-307-975-2, InTech, Available from: http://www.intechopen.com/books/herbicides-theory-and-applications/residual-herbicide-dissipation-invegetable-production

\section{INTECH}

open science | open minds

\section{InTech Europe}

University Campus STeP Ri

Slavka Krautzeka 83/A

51000 Rijeka, Croatia

Phone: +385 (51) 770447

Fax: +385 (51) 686166

www.intechopen.com

\section{InTech China}

Unit 405, Office Block, Hotel Equatorial Shanghai

No.65, Yan An Road (West), Shanghai, 200040, China

中国上海市延安西路65号上海国际贵都大饭店办公楼405单元

Phone: +86-21-62489820

Fax: $+86-21-62489821$ 
(C) 2011 The Author(s). Licensee IntechOpen. This chapter is distributed under the terms of the Creative Commons Attribution-NonCommercialShareAlike-3.0 License, which permits use, distribution and reproduction for non-commercial purposes, provided the original is properly cited and derivative works building on this content are distributed under the same license. 